\title{
Contextual information about the Peruvian national ingroup and its effect on attitudes towards a novel brand
}

\author{
Información contextual sobre el endogrupo nacional peruano \\ y su efecto en las actitudes hacia una marca novedosa
}

\author{
Ian Nightingale Ferrera ${ }^{\mathrm{a}}$ Agustín Espinosa ${ }^{\mathrm{a}, *}$ \\ ânontificia Universidad Católica del Perú, Perú
}

\begin{abstract}
The effect of contextual information about the national ingroup on explicit and implicit attitudes towards a novel brand was studied on a sample of university students from the Lima Metropolitan area $(n=59)$. The results show that the negative information about the ingroup exerts more influence on explicit attitudes towards a novel brand than the positive information. This effect is understood as a habituation of Peruvians towards the positive contextual information about their group, and an ingroup bias that acts when their national identity is threatened by the negative input. This bias guides them towards explicitly favoring a product they consider related to their social identity. On the other hand, the lack of visible results on the implicit attitudes is explained by the order effect of the Implicit Attitudes Test (IAT). These findings are relevant for advertising and marketing industries in Peru, which constantly develop campaigns that extol Peru and the Peruvian identity.
\end{abstract}

Keywords: IAT, evaluative conditioning, national ingroup, explicit attitudes, implicit attitudes.

\section{Para citar este artículo:}

Nightingale, I., \& Espinosa, A. (2018). Contextual information about the Peruvian national ingroup and its effect on attitudes towards a novel Brand. Liberabit, 24(2), 295-307. https://doi.org/10.24265/ liberabit.2018.v24n2.09

\section{Resumen}

El efecto de la información contextual sobre el endogrupo nacional en las actitudes explícitas e implícitas hacia una marca novedosa fue estudiado en una muestra de estudiantes de la ciudad de Lima $(n=59)$. Los resultados muestran que la información negativa sobre el endogrupo ejerce mayor influencia que la información positiva en las actitudes explícitas hacia una marca novedosa. Este efecto es entendido como una habituación de los peruanos hacia la información contextual positiva acerca del endogrupo, y a un sesgo endogrupal que actúa cuando la identidad nacional se ve amenazada por información negativa. Este sesgo guía a los participantes a favorecer explícitamente aquel producto que consideran está relacionado con su identidad social. Por otra parte, la falta de resultados visibles en las actitudes implícitas es explicada por el efecto del orden del Test de Actitudes Implícitas (IAT). Estos hallazgos son relevantes para las industrias de marketing y publicidad en el Perú, las cuales constantemente desarrollan campañas que exaltan el Perú y la identidad peruana.

Palabras clave: IAT, condicionamiento evaluativo, endogrupo nacional, actitudes explícitas, actitudes implícitas.

Este es un artículo Open Access bajo la licencia Creative Commons Atribución-NoComercial-CompartirIgual 4.0

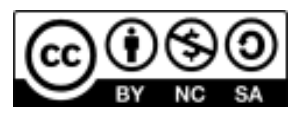


People react to the environment's stimuli in an evaluative manner, emitting favorable or unfavorable judgments about objects, events or other people (Albarracín, Zanna, Johnson, \& Kumkale, 2005). This basic human disposition lies behind one of the central concepts for psychology: attitudes. Since its introduction to social psychology (see Thomas \& Znaniecki, 1918), this construct has been conceptualized in various manners; however, these always include the concept of evaluations (Albarracín et al., 2005). One of the most accepted contemporary is that of Eagly and Chaiken (1993, p. 1), defining attitudes as «a psychological tendency that is expressed by evaluating a particular entity with some degree of favor or disfavor». This judgment is emitted towards an attitudinal object that can be any element that a person can store in his/her memory: objects, ideas, people and groups (Bohner \& Dickel, 2011).

A topic that has been of special interest in the study of attitudes, for its practical applications, has been attitude malleability. Attitudinal change happens when people process information and, as a result, develop or transform the evaluation of an object (Crano \& Prislin, 2006). Attitudes are formed and changed by various means. One way, and the most common one, comes from social learning, since social events and the behavior of other social entities are commonly the base for attitude formation. However, these can be acquired or changed by non-social means, like conditioning (Banaji \& Heiphetz, 2010).

\section{Attitude change through conditioning}

Through conditioning, individuals form positive or negative evaluations towards a neutral object (conditioned stimulus), as a result of associating it with a stimulus that inherently produces a positive or negative response (unconditioned stimulus) (Banaji \& Heiphetz, 2010). Razran (1938) was, perhaps, the first researcher to investigate the conditioned formation of attitudes using an experimental method. He read several political slogans to his participants, while providing a free meal for some of them, and found out that those who received the meal agreed more with the messages than those who did not. Staats and Staats (1958), in other two experiments, presented neutral names that were paired with positive or negative evaluative meanings. They found consistencies between the evaluations and the previous valence of the unconditioned stimulus, presumably without the awareness of the participants.

The experiments of Staats and Staats (1958) became particularly relevant because they lead to an extensive debate on the importance of awareness in conditioned formation of attitudes (Olson \& Fazio, 2001). While some studies argue that awareness is not necessary for attitudinal conditioning (e.g. Baeyens, Eelen, \& Van den Bergh, 1990), others have found positive results only on participants aware of the contingencies between stimulus (Allen \& Janiszewski, 1989; Cohen, 1964; Shimp, Stuart \& Engle, 1991). This lead to an important distinction between classical and evaluative conditioning in the formation of attitudes (Baeyens, Eelen, Crombez, \& Van den Bergh, 1992).

Evaluative conditioning differences itself from classic conditioning in three main aspects. First, and most importantly, it does not require the person to be conscious about the contingency between stimuli, an element which is necessary for the effectiveness of classic conditioning (De Houwer, 2001). Temporal association is important in classical conditioning, since it is more effective when the conditioned stimulus precedes the unconditioned one. In evaluative conditioning, stimuli are associated even if they are presented at the same time (Schimmack \& Crites, 2005). Finally, associations established through evaluative conditioning tend to be more resistant to extinction (see Hermans, Spruyt, \& Eelen, 2003).

\section{Attitude change for novel products}

Several studies have investigated the effect of evaluative conditioning on brand attitudes (Allen \& Janiszewski, 1989; Allen \& Madden, 1985; Bierley, 
McSweeney, \& Vannieuwkerk, 1985; Gibson, 2008; Kellaris \& Cox, 1989; Kim, Allen, \& Kardes, 1996; Shimp, Stuart, \& Engle, 1991; Strick, van Baaren, Holland, \& van Knippenberg, 2009; Stuart, Shimp, \& Engle, 1987). Their results have shown that the pairing of a brand with positive stimuli will produce a positive attitude towards the brand. However, the level of success in the change of attitudes has been dependent on the novelty of the conditioned stimulus. For example, Shimp et al. (1991) found that conditioning was effective when changing attitudes for novel brands but not for mature brands.

These inconsistencies have led to the distinction between different mechanisms by which evaluative conditioning affects brands. For new products, which lack previous associations stored in the memory, evaluative conditioning forms an associative network which structures an attitude towards the brand. Strick et al. (2009) investigated the effect of humor (positive US) on novel brands by associating them through evaluative conditioning. The results showed that the US had an effect on attitudes towards the novel brand, on both explicit and implicit attitudes, and on a congruent brand choice.

On the other hand, for mature brands, with an existent set of associations stored in the memory, evaluative conditioning can activate several associations that lead to a change in attitudes. Gibson (2008) studied the effect of evaluative conditioning on two popular brands (Coca-Cola and Pepsi). The experimental manipulation resulted in a change of implicit attitudes towards the brands and a brand choice congruent with the attitude change. However these results were true only for those participants who had initial neutral attitudes towards the brands and no effect was found on explicit attitudes.

The study by Gibson (2008) is part of the extensive evidence which reveals the importance of including both implicit and explicit measures for attitudes. Traditionally, studies on the topic have relied on self-report measures (usually Likert scales), which estimate explicit attitudes. Recently studies on the subject are including implicit attitude measures in order to approach automatic evaluations, since several research studies show that consumers are often guided by their automatic responses rather than propositional decision strategies (see Chartrand, 2005; Dijksterhuis, Smith, Van Baaren, \& Wigboldus, 2005). The most popular measures for automatic attitudes are the Evaluative Priming Task (Fazio, Sanbonmatsu, Powell, \& Kardes, 1986) and the Implicit Attitude Test (Greenwald, McGhee, \& Schwartz, 1998). Both are based on the idea that, if an object has a positive evaluation, it will facilitate the response towards other positive stimuli, since they share a common valence. Grounded on this proposition, they measure the response latency when associating different elements and expect that the congruence of stimuli should lead to faster responses.

\section{Information about the ingroup and attitude change}

One type of emotionally relevant stimulus, which has received virtually none attention in the study of attitude change, is the information about the ingroup. Positive and negative information about the group has an impact on the individual since it relates to the collective portion of identity and therefore affects selfesteem (Simon, 2004; Vignoles, Regalia, Manzi, Golledge, \& Scabini, 2006): this includes the perception of the national group relevant for an individual. Therefore, positive and negative information about the ingroup, acting as a US, may have an impact on attitudes towards brands when they are associated through an experimental manipulation.

The perception of the Peruvian national group is an element of interest for the Peruvian context, because of the recent presence of a nationalistic pride paradigm in consumption (Arellano, 2008; Claux, 2009). The State and various private enterprises have used the sources of national pride as a marketing tool, and have given them an increasing presence on the media (Claux, 2009; Schmitz \& Espinosa, 2015; 
Vivas, 2011). However, there is a lack of psychological studies that attempt to understand the impact, at an attitudinal level, of associating a product with information about Peru and Peruvians.

In relation to the previous statement, this study intends to investigate if the pairing with contextual information, positive or negative, about the Peruvian group can impact the formation of attitudes towards novel products. Taking into consideration the evaluative conditioning paradigm, it is hypothesized that there would be an increased preference for products associated with the positive information about Peru and Peruvians, and that the opposite will happen for products paired with the negative information.

Additionally, it is intended to find out if the influence on attitudes manifests on both the implicit evaluation of the products and the explicit preference. Taking into consideration that associations are the base of explicit attitudes (Strack \& Deutsch, 2004), it is hypothesized that there will be congruence between implicit and explicit judgments (Bizarrias \& Brandão, 2017).

\section{Method}

\section{Participants}

Fifty-nine (59) university students (24 males, mean age: $18.54, S D=1.87$ ) of a private university in the Lima Metropolitana area participated in the study. Socio-economical level was controlled between the participants in order to maintain a homogeneous group according to this variable. Moreover, the criteria for selecting participants with these characteristics were: (1) Accessibility to the sample, and (2) High-educated participants that could understand the statements of the data-gathering materials.

\section{Stimulus materials}

\section{Web page images for the pairing of stimuli}

This tool intended the stimuli to be paired in a nonintrusive environment. Ten images that resembled a well-known web page in Peru were constructed. Every image presented one of the products and a short text (between 100 and 140 words) with positive (positive condition) or negative information (negative condition) about the Peruvian group: one of the products was systematically paired with the positive content and the other one with the negative information. Additionally, the images included filler pictures to make the pages more natural for the participant.

In order to prevent the possible influence of the products' characteristics, the pairing between the brands and the texts of both conditions was counterbalanced: the assignment of the brand to the positive or negative condition was inverted in the two different versions of the web page images.

Pisco bottles of existing brands were used as novel products in the experiment, because of the strong relationship between pisco and the Peruvian sentiment. This product has been recently converted into a powerful national symbol (Titinger, 2006), and evaluative conditioning is more effective when there is a link between the paired stimuli (De Houwer, 2001).

Each picture was edited in order to maintain a common resolution, size and grey background for all the bottles. All the images included the brand name in the left area of the picture, in the same color, font and size of the writing. On the other hand, the topics of the texts were gastronomy, tourism, Peruvians' attributes, entrepreneurship and competence.

\section{Implicit attitude test (IAT)}

The IAT (Greenwald et al., 1998) was used for the measurement of implicit attitudes towards novel products. It measures the strength of the automatic relationship between an object and an evaluation.

Various research studies have demonstrated the robustness of the IAT. Its test-retest reliability measures are, on average, $r=.60$. Also, in relation to its convergent validity, strong correlations have been 
found between the IAT and the priming task. Additionally, it is useful in predicting the tendency of people to favor their own group, which brings evidence of the construct validity of the tool (see Dasgupta \& Greenwald, 2001).

\section{Product attractiveness}

The product attractiveness scale was included in order to assess the explicit attitude towards each brand. Answers are given on a scale from 1 to 5 , where 1 means «Not attractive at all» and 5 means «Very attractive». The term «attractive» was used because it relates closely to a visual evaluation of the product, while the word "goodness» in Spanish is related to an evaluation of the product flavor, which possibly could confuse the participants.

\section{Manipulation check}

Participants rated each one of the texts, both positively and negatively, on a scale from 1 to 5 , where 1 means «Not proud at all» and 5 means «Very proud». This task had the intention of assessing if the independent variable was having the desired effect, and if the positive texts evoked more national pride in the participants than the negative texts.

As expected, the averages contrast proved that the texts with positive information, $M=4.15, S D=.65$, evoked more pride than the negative texts, $M=1.72$, $S D=.66, t(59)=20.99, p<.001,95 \%$ CI $[2.20$, 2.66].

\section{Demand awareness}

Participants were asked to guess the experiment's hypothesis and report any element they had observed that could be related to the objectives of the research. This task had the intention of noticing people that could be aware of the study's hypothesis or could have detected the pairing of stimuli in the web page images.

\section{Procedure}

Two pilot studies with the aim of selecting the stimuli for the experiment were conducted using groups ( $n=10$ in both cases) with similar characteristics to the experimental sample. The first pilot was oriented to select, based on their level of attractiveness, the images of bottles of pisco that would be used in the application. The second pilot was aimed to select the contextual information (positive or negative) about the ingroup that would be used to accompany the images of the bottle of pisco being evaluated during the application. Thus, as a result of both pilots, the texts (contextual information about ingroup) that would be included in the application, the images of two products (bottles of pisco) that had a statistically equivalent level of attractiveness, and the least salient neutral images to be used as fillers were obtained.

During the experiment, the application was conducted individually. Participants were told that they were part of a study about media coverage of events. Each person had a computer assigned and was told to open the web page images for the pairing of stimuli. They were instructed to read the texts thoroughly, because they were going to answer questions about their content.

Each one of the ten images included in this tool was presented on the computer screen for forty-five seconds. Of the fifty-nine participants, thirty saw the version 1 of the images, where Pisco A was related to the positive content, and twenty-nine saw the version 2, where Pisco B was related to the positive information.

Once the presentation of this tool finished, participants indicated the level of pride they felt when they read each one of these texts and responded the demand awareness task about the hypothesis of the research. The measurement of implicit attitudes followed. The seven blocks that composed the IAT presented stimuli in front of a black background, centered both horizontally and vertically. 
Table 1

Sequence of the trial blocks in the IAT

\begin{tabular}{ccccc}
\hline Block & No. of trials & Function & Items assigned to the left key & Items assigned to the right key \\
\hline 1 & 20 & Practice & Pleasant words & Unpleasant words \\
2 & 20 & Practice & Images of Pisco A & Images of Pisco B \\
3 & 20 & Practice & Pleasant words + Pisco A & Unpleasant words + Pisco B \\
4 & 40 & Test & Pleasant words + Pisco A & Unpleasant words + Pisco B \\
5 & 40 & Practice & Images of Pisco B & Images of Pisco A \\
6 & 40 & Practice & Pleasant words + Pisco B & Unpleasant words + Pisco A \\
7 & 40 & Test & Pleasant words + Pisco B & Unpleasant words + Pisco A \\
\hline
\end{tabular}

Note: The number of trials in blocks five and six differs from the standard application of the IAT, where twenty trials are used. The aim of this increase was to reduce the order effect on the experiment results (Greenwald, Banaji, \& Nosek, 2003). Additionally, the order in which the pisco brands were assigned to the categories «Good» and «Bad» was counterbalanced to avoid its influence.

Table 1 describes the sequence of tasks presented on the IAT. In the first block, participants assigned the pleasant words to the evaluative category «Good» and the unpleasant words to the category «Bad». The second block required the person to discriminate between images of Pisco A and Pisco B, and assign them to their corresponding categories. Blocks three and four required the assignment of the pleasant words together with Pisco A to the category «Good», and the unpleasant words together with Pisco B to the category «Bad». Block three was the practice for the test, which was presented on the fourth one. Blocks five, six and seven required the same as the blocks that preceded them, with the difference that they interchanged the assignment of the pisco brands to each one of the evaluative categories (Greenwald et al., 2003; Greenwald et al., 1998).

The pleasant and unpleasant words that were classified in each one of the categories were: «Good»: positive, triumph, joy, happiness and enjoyment; «Bad»: negative, failure, pain, misfortune, sickness (Briñol, Horcajo, Beccera, Falces, \& Sierra, 2002). In the forty trial blocks, each image was presented ten times and each word twice, on a random order.
Finally, participants responded to the product attractiveness scale, where they reflected their explicit preference for one brand, and to the control data questionnaire. Furthermore, they were asked if they knew the pisco brands which were presented and if they had any contact with the brand the test considered invalid.

Once the application phase ended, the collected information was transferred to a database for conducting a statistical analysis. First, one case was removed from the analysis because the person indirectly detected the hypothesis of the experiment. Once it was eliminated, a normality test and an average contrast were obtained for the manipulation check in order to confirm that the positive information really evoked more pride in the participants than the negative texts.

On the other hand, in order to get an improved score of the IAT, too slow or fast responses were reencoded $^{1}$ : answers faster than $300 \mathrm{~ms}$ were changed to $300 \mathrm{~ms}$ and slower than $3000 \mathrm{~ms}$ were re-encoded to $3000 \mathrm{~ms}$. Additionally, the measures were transformed towards a logarithmic distribution (base

1 These were re-encoded because they lack theoretical interest, distort the averages and inflate variances. 
10), with the aim of giving them an acceptable variance for the analysis. These changes to the data are the same Greenwald et al. (1998) use in the conventional algorithm of the IAT.; This was chosen, rather than the improved algorithm, because it is less sensitive to the order effect (Greenwald et al., 2003).

An average contrast was conducted for the transformed scores of the congruent and incongruent conditions $^{2}$. The same procedure was done for the product attractiveness, the measure of explicit attitudes, in order to evaluate possible differences between attitudes towards the brand related to the positive and negative information.

Furthermore, the variables of IAT effect and Explicit effect were constructed to find out, from a correlation, if there was a relationship between both attitude measurements. The IAT effect was obtained by subtracting the transformed scores of the congruent condition from the incongruent one, and the Explicit effect was constructed by subtracting the score of attractiveness of the brand related to the negative information from the one related to the positive information.

Finally, a correlation was obtained between the block presentation order and the implicit effect to assess if the order effect was influencing the IAT scores. The order was constructed as a dichotomous variable, where a score of two implied that the congruent block was presented first and a score of one meant the contrary. These scores were categorized considering that the order effect should appear as a positive value in the correlation.

\section{Results}

The congruent condition of the implicit attitudes ${ }^{3}$, $M=2.91 ; S D=.10$, did not show a statistically significant difference compared to the incongruent condition, $M=2.91 ; S D=.09, t(59)=0.17 ; p=$ $.87 ; 95 \% \mathrm{CI}=[-.025, .030]$. This result confirms the implicit measure of attitudes did not find a significant effect of the experimental manipulation on the product attitudes.

In regard to the product attractiveness, the explicit attitude measure, the brand related to the positive information, $M=3.03 ; S D=1.05$, obtained a lower attractiveness score than the one related to the negative information, $M=3.39 ; S D=1.02 ; t(59)=$ 1.95; $p<.06$; 95\% CI $=[-.721, .009]$. Based on the criteria by Hemphill (2003), there was a medium effect size, $d=.235$ and power $=.66$. This result does not accept the hypothesis in which the brand associated with the positive information would show a more positive attitude compared to the one related to the negative information. It confirms the opposite: the product related to the negative information was perceived as more attractive.

Additionally, the Spearman correlation analysis found no relationship between the implicit and explicit effects, $r_{s}(59)=.06 ; p=.24 ; 95 \% \mathrm{CI}=[-.204, .352]$. This result does not accept the hypothesis in which there would be a correlation between the implicit and explicit attitudes towards the pisco brands.

Finally, the influence of the order effect on the IAT scores was assessed. The correlation between these variables found an important and significant order effect, $r_{s}(59)=.55 ; p<.001 ; 95 \%$ CI $=[.321, .740]$. Block four got faster latency scores than block seven, regardless if it was the congruent or incongruent condition.

\section{Discussion}

People who identify themselves with a social group are motivated to keep a positive concept of it (Tajfel \& Turner, 1986). One way in which this motivation

In the congruent condition, the brand associated with the positive information is cataloged in the category «Good», and the brand associated with the negative information in the category «Bad»; the opposite happens in the incongruent condition.

3 Analyses were performed with the transformed IAT scores. 
materializes is in the ingroup favoritism or bias: the tendency of people to favor or value positively one's group (Brewer, 1999; Turner, Brown \& Tajfel, 1979). This concept can prove useful to understand the unexpected results in the explicit attitudes towards novel products. Negative information about the ingroup represents a direct menace to the social identity of the person and, therefore, to his/her selfesteem. Confronted with that threat, the ingroup bias could have been activated in order to protect one's identity by favoring the ingroup and the elements related to it. In this case, those elements included the bottle of pisco, a product with an intrinsic relationship with the Peruvian national sentiment (Titinger, 2006).The result is that the bottle of pisco which accompanied the menacing information was perceived as a more attractive brand, because threatened consumers were unconsciously favoring it. This effect could have been magnified by the fact that menaces to an individual's self diminishes his/her confidence, which makes him/her more prone to an attitudinal change (Briñol \& Petty, 2009).

Other possible explanation comes from a human tendency to protect themselves from persuasion. The Flexible Correction Model (Wegener \& Petty, 1997) argues that people constantly search to reduce bias from their judgments. An individual that realizes that his/her positive mood could affect his/her perceptions in a positive manner could attempt to reduce this influence, in a process that could end up in a less positive attitude (see DeSteno, Petty, Wegener, \& Rucker, 2000). Additionally, if participants were, at some point, aware of any type of «contamination» in their information processing, they would correct their judgment and become less positive or even negative (e.g., Berkowitz, Jaffee, Jo, \& Troccoli, 2000; DeSteno et al., 2000).

In regard to the brand associated with the positive information, it is worth mentioning that in previous years there has been a constant flow of information coming from various sources like advertisements of private enterprises (Claux, 2009; Vivas, 2011) and the
Central Government (PROMPERÚ, 2011), which favors Peruvians and extols the attributes of their country. The constant exposure to this type of information about their group could have caused a habituation: the continuous repetition of the stimulus causes a decrease in the response of pride towards the positive information (Razran, 1971), or perhaps this kind of enthusiastic information about the country appears as inconsistent with Peruvian social reality mitigating its positive effect (Schmitz \& Espinosa, 2015). Although this is only an inference, it could pose a doubt for advertisements which emphasize an ideal image of Peru and Peruvians, without relating this to the product. It may be that the success of some nationalistic advertisement campaigns, like Inca Kola (soda) or Sapolio (cleaning products) (Arellano, 2008) is due to the relationship established previously between the product and the information. When this link is not evident, like in the experimental application in this research, the attitudinal change is not successful.

Previous considerations translate into the fact that a novel brand obtains greater benefit, at an attitudinal level, by relating itself with negative rather than positive information about the ingroup. However, it is highly probable that this effect would not be present for products not related to the group or nation of the person involved: ingroup favoritism would not be activated unless the individual identifies a relationship between the stimulus and his/her social identity. Additionally, as it was mentioned before, evaluative conditioning is more effective when there is a mild relationship between the unconditioned and conditioned stimuli, as it occurs between the information about Peru and pisco.

On the other hand, regarding implicit attitudes, Messner and Vosgerau (2009) consider that the order effect is crucial for understanding the internal validity of the IAT, because it can introduce an external influence that eliminates or reverses the effect of this measure. These same authors argue that this influence happens because of cognitive inertia: the difficulty of changing 
a categorization rule for an opposite one (Messner \& Vosgerau, 2010). In this research, the order effect has made itself visible on the results, even when the recommendations to reduce its influence were followed and the conventional algorithm was used, which is more resistant to order. This could have contributed to the lack of significant results for the implicit measure. Therefore, this study adds up to an important theoretical corpus which challenges the IAT's validity, because it includes the measurement of other independent variables not considered by researchers (Brendl, Markman, \& Messner, 2001; Mierke \& Klauer, 2001; Rothermund \& Wentura, 2001).

Another possible explanation for the IAT's results is based on the nature of the stimuli utilized. Previously examined research used the IAT to measure well-consolidated attitudes (for example, attitudes towards ethnic groups) (Brendl et al., 2001; Nosek, Greenwald, \& Banaji, 2005) or attitudes created with powerful emotional stimuli, with direct influence on attitudes (for example, humor) (Strick, et al., 2009). Although the independent variable in this study (positive information about the ingroup) has a clear emotional influence, its nature is basically propositional. This explains the changes seen on the explicit measure, since propositions are the base for this type of attitudes (Bohner \& Dickel, 2011), while the implicit measure remained unaltered.

Additionally, the information presented implied a high-order cognitive processing, which results in a slower implicit attitude change (Rydell \& McConnell, 2006). Because of this, and considering that propositions can be the base for implicit attitudes (Gawronski \& Bodenhausen, 2007), future research should consider performing the automatic measure after a longer period of time. This could result effective when expecting a change in the implicit attitude towards novel brands.

On other topic, the results are congruent with a strong theoretical corpus that finds a dissociation between implicit and explicit attitudes (Conrey,
Sherman, Gawronski, Hugenberg, \& Groom, 2005; Greenwald et al., 2009; Rydell et al., 2007). This supports the idea that there are two different mechanisms which operate behind both types of attitudes (Gawronski \& Bodenhausen, 2007).

Finally, according to the arguments presented above, it becomes evident that products and nations can develop strong relationships. Some of these products and brands are incorporated in the country's national scheme and can have some impact in the construction of the identity of this nation. In this sense, manufacturers and people in charge of promoting these products have a great responsibility. Undoubtedly, there is a necessity to continue studying the bidirectional relationship between a nation and the products that represent it.

\section{Limitations and future trends}

Based on the aforementioned description, this study is limited due to the lack of greater sociodemographic variability in the participants. This means that inferences corresponding to the present study are just valid for the sample that participated in it, and reasonable inferences could be extended to a population with similar characteristics to those of the participants. In that sense, more research is recommended to analyze the effect of contextual information about a country on the explicit and implicit attitudes towards novel brands and products that will be associated to said country.

\section{Conflicts of interest}

The authors declare that there are no (moral, economic, workplace and research) conflict of interests.

\section{Ethical responsibility}

The principles of voluntariness, anonymity and confidentiality have been applied. All participants have been duly informed of their rights, as well as the fact that participating (or failing to do so) does not pose 
any risk or situation detrimental to them. Informed consent was applied in all cases.

Also, given the characteristics of the study (conditions of application, nature of the tests), it is considered that the same does not pose risk conditions for participants.

The data has been registered in a digital platform. Participants cannot be identified through their responses, since the identity markers have not been requested. Otherwise, if they had been requested, they would have been eliminated once the collection of data was completed.

\section{References}

Albarracín, D., Zanna, M. P., Johnson, B. T., \& Kumkale, G. T. (2005). Attitudes: Introduction and scope. In D. Albarracín, B. T. Johnson, \& M. P. Zanna (Eds.), The handbook of attitudes (pp. 3-20). Mahwah, NJ: Lawrence Erlbaum Associates Publishers.

Allen, C. T., \& Janiszewski, C. A. (1989). Assessing the role of contingency awareness in attitudinal conditioning with implications for advertising research. Journal of Marketing Research, 26, 30-43.

Allen, C. T., \& Madden, T. J. (1985). A Closer Look at Classical Conditioning. Journal of Consumer Research, 12, 301-315.

Arellano, R. (2008). Bueno, bonito y barato (Vol. 2). Lima: Planeta.

Baeyens, F., Eelen, P., Crombez, G., \& Van den Bergh, O. (1992). Human evaluative conditioning: Acquisition trials, presentation schedule, evaluative style, and contingency awareness. Behavior Research and Therapy, 30, 133-142. doi:10.1016/0005-7967 (92)90136-5

Baeyens, F., Eelen, P., \& Van den Bergh, O. (1990). Contingency awareness in evaluative conditioning: A case for unaware affective-evaluative learning. Cognition and Emotion, 4, 3-18.

Banaji, M. R., \& Heiphetz, L. (2010). Attitudes. In D. T. Gilbert \& S. T. Fiske (Eds.), Handbook of Social
Psychology (pp. 353-393). Hoboken, NJ: John Wiley \& Sons.

Berkowitz, L., Jaffee, S., Jo, E., \& Troccoli, B. (2000). Some conditions affecting overcorrection of the judgment-distorting inûuence of one's feelings. In J. P. Forgas (Ed.), Feeling and thinking: The role of affect in social cognition. Cambridge, England: Cambridge University Press.

Bierley, C., McSweeney, F. K., \& Vannieuwkerk, R. (1985). Classical Conditioning of Preferences for Stimuli. Journal of Consumer Research, 12, 316323.

Bizarrias, F., \& Brandão, M. (2017). Proposta de modelo conceitual de atitudes implícitas e explícitas no varejo. Revista Brasileira de Marketing, 16(4),454468. doi: 10.5585/remark.v16i4.3664

Bohner, G., \& Dickel, N. (2011). Attitudes and attitude change. Annual Review of Psychology, 62, 391-417. doi:10.1146/annurev.psych.121208.131609

Brendl, C. M., Markman, A. B., \& Messner, C. (2001). How do indirect measures of evaluation work? Evaluating the inference of prejudice in the Implicit Association Test. Journal of Personality and Social Psychology, 81, 760-773. doi:10.1037//0022-351 4.81.5.760

Brewer, M. B. (1999). The psychology of prejudice: Ingroup love or Outgroup hate? Journal of Social Issues, 55, 429-444. doi:10.1111/0022-4537.00126

Briñol, P., Horcajo, J., Becerra, A., Falces, C., \& Sierra, B. (2002). Cambio de actitudes implícitas. Psicothema, 14, 771-775.

Briñol, P., \& Petty, R. E. (2009). Persuasion: Insights from the self-validation hypothesis. Advances in Experimental Social Psychology, 41, 69-118. doi:10.1016/S0065-2601(08)00402-4

Chartrand, T. L. (2005). The role of conscious awareness in consumer behavior. Journal of Consumer Psychology, 15, 203-210.

Claux, D. (2009). «Tengo el Orgullo de ser Peruano y Soy Feliz» Upper Class Limeños, National Identity, and Cultural Change in the 21st Century (Unpublished master's thesis). Institute for the Study of the Americas, London, United Kingdom. 
Cohen, B. H. (1964). Role of awareness in meaning established by classical conditioning. Journal of Experimental psychology, 67, 373-378

Conrey, F. R., Sherman, J. W., Gawronski, B., Hugenberg, K., \& Groom, C. J. (2005). Separating multiple processes in implicit social cognition: The quad model of implicit task preference. Journal of Personality and Social Psychology, 89, 469-487. doi:10.1037/0022-3514.89.4.469

Crano, W. D., \& Prislin, R. (2006). Attitudes and persuasion. Annual Review of Psychology, 57, 345374. doi:10.1146/annurev.psych.57.102904.190034

Dasgupta, N., \& Greenwald, A. G. (2001). On the malleability of automatic attitudes: Combating automatic prejudice with images of admired and disliked individuals. Journal of Personality and Social Psychology, 81, 800-814. doi:10.1037//00223514.81.5.800

De Houwer, J. (2001). Contingency awareness and evaluative conditioning: When will it be enough? Consciousness \& Cognition: An International Journal, 10, 550-558. doi:10.1006/ccog.2001.0528

DeSteno, D., Petty, R. E., Wegener, D. T., \& Rucker, D. D. (2000). Beyond valence in the perception of likelihood: The role of emotion speciûcity. Journal of Personality and Social Psychology, 78, 397-416.

Dijksterhuis, A., Smith, P. K., van Baaren, R. B., \& Wigboldus, D. (2005). The Unconscious Consumer: Effects of Environment on Consumer Behavior. Journal of Consumer Psychology, 15, 193-202.

Eagly, A. H., \& Chaiken, S. (1993). The Psychology of attitudes. Orlando, FL: Harcourt Brace Jovanovich.

Espinosa, A. (2011). Estudios sobre identidad nacional en el Perú y sus correlatos psicológicos, sociales y culturales (Unpublished doctoral dissertation). Universidad del País Vasco, San Sebastián, Spain.

Fazio, R. H., Sanbonmatsu, D. M., Powell, M. C., \& Kardes, F. R. (1986). On the automatic activation of attitudes. Journal of Personality and Social Psychology, 50, 229-238. doi:10.1037//0022-3514. 50.2.229

Gawronski, B., \& Bodenhausen, G. V. (2007). Unraveling the process underlying evaluation: attitudes from the perspective of the APE model. Social Cognition, 25, 687-717. doi:10.1521/soco.2007.25.5.687

Gibson, B. (2008). Can evaluative conditioning change attitudes toward mature brands? New evidence from the Implicit Association Test. Journal of Consumer Research, 35, 178-188.

Greenwald, A. G., \& Banaji, M. R. (1995). Implicit social cognition: Attitudes, self-esteem, and stereotypes. Psychological Review, 102, 4-27. doi:10.1037//00 33-295X.102.1.4

Greenwald, A. G., Banaji, M. R., \& Nosek, B. A. (2003). Understanding and using the implicit association test: I. An improved scoring algorithm. Journal of Personality and Social Psychology, 85, 197-216. doi:10.1037/0022-3514.85.2.197

Greenwald, A. G., McGhee, D. E., \& Schwartz, J. L. K. (1998). Measuring individual differences in implicit cognition: The implicit association test. Journal of Personality and Social Psychology, 74, 1464-1480. doi:10.1037//0022-3514.74.6.1464

Hemphill, J. F. (2003). Interpreting the magnitudes of correlation coefficients. American Psychologist, 58, 78-80. doi:10.1037/0003-066X.58.1.78

Hermans, D., Spruyt, A., \& Eelen, P. (2003). Automatic affective priming of recently acquired stimulus valence: Priming at SOA 300 but not at SOA 1000. Cognition \& Emotion, 17, 83-99. doi:10.1080/02 699930302276

Kellaris, J. J., \& Cox, A. D. (1989), The Effects of Background Music in Advertising: A Reassessment. Journal of Consumer Research, 16, 113-18.

Kim, J., Allen, C. T., \& Kardes, F. R. (1996). An Investigation of the Mediational Mechanisms Underlying Attitudinal Conditioning, Journal of Marketing Research, 33, 318-328.

Messner, C., \& Vosgerau, J. (2010). Cognitive Inertia and the Implicit Association Test. Journal of Marketing Research, 47, 374-386. doi:10.1509/jmkr.47.2.374

Messner, C., \& Vosgerau, J. (2009). Order Effects in the IAT. Advances in Consumer Research, 36, 38-40.

Mierke, J., \& Klauer, K. C. (2001). Implicit association measurement with the IAT: Evidence for effects of 
executive control processes. Experimental Psychology, 48, 107-122. doi:10.1026//0949-394 6.48.2.107

Nosek, B. A., Greenwald, A. G., \& Banaji, M. R. (2005). Understanding and using the Implicit Association Test: II. Method variables and construct validity. Personality and Social Psychology Bulletin, 31, 166-180. doi:10.1177/0146167204271418

Olson, M. A., \& Fazio, R. H. (2001). Implicit attitude formation through classical conditioning. Psychological Science, 12, 413-417

Prom Perú (2011). Uso de la marca país. Página oficial de la marca país: Perú. Retrieved from http://www. peru.info/

Razran, G. H. S. (1938). Conditioning away social bias by the luncheon technique. Psychological Bulletin, 37,481 .

Razran, G. H. S. (1971). Mind in evolution: An East-West synthesis of learned behavior and cognition. Boston: Houghton Mifflin.

Rothermund, K., \& Wentura, D. (2004). Underlying processes in the Implicit Association Test: Dissociating salience from associations. Journal of Experimental Psychology: General, 133, 139-165. doi:10.1037/0096-3445.133.2.139

Rothermund, K., \& Wentura, D. (2001). Figure ground asymmetries in the Implicit Association Test. Experimental Psychology, 48, 94-106. doi:10.1026/ /0949-3946.48.2.94

Rydell, R. J., \& McConnell, A. R. (2006). Understanding implicit and explicit attitude change: A systems of reasoning analysis. Journal of Personality and Social Psychology, 91, 995-1008. doi:10.1037/002 2-3514.91.6.995

Rydell, R. J., McConnell, A. R., Strain, L. M., Claypool, H. M., \& Hugenberg, K. (2007). Implicit and explicit attitudes respond differently to increasing amounts of counterattitudinal information. European Journal of Social Psychology, 37, 867-78. doi:10.1002/ejsp.393

Schimmack, U., \& Crites, S. L. (2005). The structure of affect. In D. Albarracín, B. T. Johnson, \& M. P. Zanna (Eds.), The handbook of attitudes (pp. 397-435).
Mahwah, NJ: Lawrence Erlbaum Associates Publishers.

Schmitz, M., \& Espinosa, A. (2015). Impacto de la información disonante y consistente sobre la campaña Marca Perú en la identidad nacional y el bienestar social. Universitas Psychologica, 14(1), 329-338. doi:10.11144/Javeriana.upsy13-5.iidc

Simon, B. (2004). Identity in a modern society: A social psychological perspective. Oxford: Blackwell.

Shimp, T. A., Stuart, E. W., \& Engle, R. W. (1991). A program of classical conditioning experiments testing variations in the conditioned stimulus and context. Journal of Consumer Research, 18, 1-22.

Staats, A. W., \& Staats, C. K. (1958). Attitudes established by classical conditioning. Journal of Abnormal and Social Psychology, 11, 187-192.

Strack, F., \& Deutsch, R. (2004). Reflective and impulsive determinants of social behavior. Personality and Social Psychology Review, 8, 220-247. doi:10.1207/ s15327957pspr0803_1

Strick, M., van Baaren, R. B., Holland, R. W., \& van Knippenberg, A. (2009). Humor in advertisements enhances product liking by mere association. Journal of Experimental Psychology: Applied, 15(1), 35-45. doi: $10.1037 / \mathrm{a} 0014812$

Stuart, E., Terrence, W., Shimp, A., \& Engle, R. W. (1987). Classical Conditioning of Consumer Attitudes: Four Experiments in an Advertising Context, Journal of Consumer Research, 14, 334-49.

Tajfel, H., \& Turner, J. C. (1986). The social identity theory of inter-group behavior. In S. Worchel, \& L. W. Austin (Eds.), Psychology of Intergroup Relations. Chicago: Nelson-Hall.

Titinger, D. (2006). Dios es peruano. Lima: Planeta.

Thomas, W. I., \& Znaniecki, F. (1918). The Polish peasant in Europe and America. Boston: Badger.

Turner, J. C., Brown, R. J., \& Tajfel, H. (1979). Social comparison and group interest in ingroup favouritism. European Journal of Social Psychology, 9, 187-204. doi:10.1002/ejsp.2420090207 
Vignoles, V. L., Regalia, C., Manzi, C., Golledge, J., \& Scabini, E. (2006). Beyond self-esteem: Influence of multiple motives on identity construction. Journal of Personality and Social Psychology, 90, 308-333.

Vivas, F. (2011, Marzo 19). Spots con rollo. El Comercio.pe. Retrieved from http://elcomercio.pe/ impresa/notas/mucho-ojo-spots-rollo/20110319/ 729627
Wegener, D. T., \& Petty, R. E. (1997). The Flexible Correction Model: The role of naive theories of bias in bias correction. In M. P. Zanna (Ed.), Advances in experimental social psychology (Vol. 29, pp. 141208). Mahwah, NJ: Erlbaum.

Ian Nightingale Ferrer

Pontificia Universidad Católica del Perú

Bachiller en Letras y Ciencias Humanas con Mención en Psicología (PUCP), Licenciado en Psicología con Mención en Psicología Social (PUCP). Ha sido Docente TPA del Departamento Académico de Psicología (PUCP).

nightingale.ian@pucp.pe

Agustín Espinosa

Pontificia Universidad Católica del Perú

Bachiller en Letras y Ciencias Humanas con Mención en Psicología (PUCP), Licenciado en Psicología con Mención en Psicología Social (PUCP). Doctor en Psicología Social por la Universidad del País Vasco, España. Profesor ordinario del Departamento Académico de Psicología (PUCP).

ORCID: 0000-0002-2275-5792

Autor corresponsal: agustin.espinosa@pucp.pe 